\title{
OBITUARIES
}

Obituaries should be submitted by email to Laura Pacey at I.pacey@nature.com.

All submitted obituaries should be 450 words maximum in length (apart from obituaries for past presidents of the BDA where the length should be 800 words).

Content of the obituary is down to the individual author, and the approval of the family should

be given for the obituary prior to submission to the $B D J$.

\section{WILLIAM DAVID STALLEY}

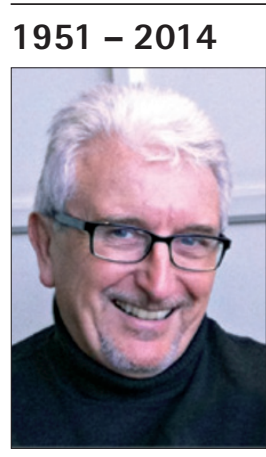

They broke the mould with Bill Stalley who died on the 24 April after a short illness. As with everything to which Bill applied himself, he faced his denouement with a characteristic stoic dignity.

Bill qualified from Birmingham Dental Hospital in 1974, taking up a dental houseman's job for a year at the hospital. Bill then took associate positions in Solihull and Stirchley whilst maintaining a part time role with the Dental Hospital. Bill formed a partnership with Robert Shaw in 1978 and was involved with several practices in the area. Latterly Bill set up a single-handed private practice in Dorridge, where he practised until his recent illness.

Bill applied himself with avid zeal to whatever he turned his hand to. He was a keen athlete. He completed several marathons and was a competitive cyclist. In his younger days he played rugby for a Hartlepool club. Bill was also an accomplished and enthusiastic golfer.

Bill was highly regarded by his patients and had the ability to put people at their ease even whilst wielding an air rotor and hiding behind a mask.

In addition to dentistry Bill retrained in addictive medicine in the UK and in the USA at the University of Utah. He worked part time for 20 years with Joe Mee and other colleagues with the Dentists Health Support Programme.

The aim of the programme is to intervene and support anyone involved with the dental profession who is affected by alcoholism or other addictions. Bill did good by stealth. He spent much of his free time travelling around the country when asked to help colleagues in difficulty. His experience and expertise in the field of addiction was of immeasurable help to many colleagues and family members.

'Bill, how could I forget him? A great bloke. Tall, quietly spoken. Snappy dresser: silk ties and bespoke doublebreasted suits. He put in a lot of legwork keeping me on the straight and narrow from my heroin addiction.' (C. G.: son of a London dentist)

'Bill Stalley salvaged my livelihood and marriage. It's no exaggeration to say that he probably saved my life.' (F. D.: dentist, Yorkshire)

'Bill reminds me of a benign Rottweiler. He never gave up on our family and we owe him a big debt of gratitude.' (A.

H.: dentist, Nottinghamshire)

It was standing room only at the funeral on the 9 May. More than 300 people packed St. Paul's Church in Warwick: a testament to the many whose lives had been touched by Bill's influence. Bill was a gentle unassuming giant who many regarded as one of life's unsung heroes.

Our thoughts are with Bill's wife Jane, his daughters Rachael, Carla and Nicky and his extended family.

James Willis

\section{WILFRED GEORGE SELLEY}

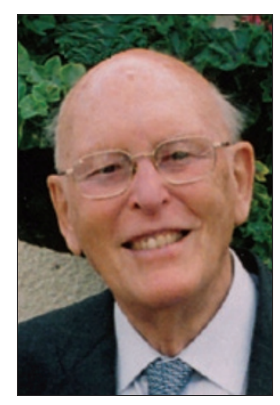

$1926-2014$

Wilfred George Selley of Exeter sadly passed away on 1 March 2014 aged 88. In 1948 Wilf graduated from Guy's Hospital where there was a wonderful spirit, despite being war

time with German rockets falling. He recalled that he took his best plaster impression when holding the tray still, whilst the patient and building vibrated!

After qualifying, Wilf spent four months working in the new preventative dentistry department before being posted to Sandhurst to join the
Royal Army Dental Corp undertaking 18 months of National Service.

In 1951 he returned to Exeter and joined his father's practice, although he continued his academic study and gained his FDSRCS in 1952. He was appointed part-time associate specialist oral surgeon at Royal Devon and Exeter Hospital from 1951-1991.

In the early 1960s Wilf increased his hospital sessions, developing a special interest in the early management of cleft palate babies and started combined plastic/speech/dental clinics. This led on to research between 1975-2000 as an Honorary Research Fellow, Medical Physics Group, University of Exeter and the development of objective noninvasive diagnostic aids related to "cleft palate type speech' and further research regarding the co-ordination of sucking, swallowing and breathing in feeding infants. His reputation and research required him to lecture in the USA, Europe, Jordan and Singapore. He had 32 publications.

He was awarded an Honorary Fellowship by the Royal College of Speech and Language Therapy in 1987. He was an active member of the LDC and BDA and was elected President of the Western Counties Branch in 1975. He retired from general practice in 1986 but continued his work with a five year emeritus appointment at the Royal Devon and Exeter Hospital. He always thought he was fortunate to have combined general practice, the stimulus of his hospital appointment and his research.

Wilf was happily married to Audrey for 64 years. He was a wonderful inspirational father to their four sons and one daughter, adored grandfather to 14 grandchildren and 4 great grandchildren. His son Mike and daughter Liz followed his footsteps into the profession as did his grandson Charles who is currently training, a third generation at Guy's!

Liz Pidgeon 